\title{
21st Century Competencies in Light of the History of Integrated Curriculum
}

\author{
Susan M. Drake* and Joanne L. Reid \\ Faculty of Education, Brock University, St. Catharines, ON, Canada
}

Integrated or interdisciplinary curriculum (IC) is an effective and relevant way to teach the 21st century competencies and to apply the transdisciplinary skills necessary for solving complex global problems. We review the underpinnings of both traditional and progressive education and past periods of implementation of IC in order to understand its history. Multiple definitions of IC are identified on a continuum. Reasons to dismiss the continuum are also offered. Two periods when IC was implemented in a consistent way in the United States are explored: the progressive era from 1919 to 1955, and the late 1980s and early 1990s. Similarities in each era are identified such as progressive principles of teaching and learning. Differences are also considered in basic assumptions held by curriculum developers of the day with the 1980s and 1990s lacking the 1930s deep social purpose of teaching for a democratic society. The socio-political

OPEN ACCESS

Edited by:

Stephen J. Farenga,

Queens College (CUNY),

United States

Reviewed by:

Richard Sawyer

Washington State University

Vancouver, United States

Salvatore G. Garofalo,

Queens College (CUNY), United States

*Correspondence: Susan M. Drake sdrake@brocku.ca

Specialty section: This article was submitted to Leadership in Education, a section of the journal

Frontiers in Education

Received: 17 December 2019 Accepted: 18 June 2020

Published: 14 July 2020

Citation:

Drake SM and Reid JL (2020) 21st Century Competencies in Light of the History of Integrated Curriculum. Front. Educ. 5:122. doi: 10.3389/feduc.2020.00122 context is visited to understand the beginnings and endings of these eras. The current educational context is then viewed from a global context. We see a landscape in which accountability and disciplines are counterbalanced by a global redefinition of what's worth knowing and a shift toward interdisciplinary competencies/skills/capabilities, wellbeing and teaching the whole child. Indeed, this is happening in places around the planet such as Finland. The ideas are reminiscent of the 1930s progressive movement-a time of experimentation when student interests and needs more than disciplinary content shaped an IC. We propose that the current global conversation can offer conceptual cohesion to encourage and support the implementation of IC and can act as a proxy for the Progressive Education Association that guided practitioners from 1919 to 1955.

Keywords: integrated curriculum, interdisciplinary curriculum, progressive education, twenty-first century competencies, history of integrated curriculum

\section{INTRODUCTION}

The 21st century competencies are recognized internationally as crucial skills for students, and integrated/interdisciplinary curriculum (IC) is recognized as an effective teaching/learning model to address these skills. IC reaches back to the Progressive Era of the 1930s. How can IC's history inform curriculum design for the 21st century?

This article explores two periods when IC was implemented in a consistent way: the progressive era from 1919 to 1955, and the late 1980s and early 90s. We focus on the United States although we acknowledge that progressive education and IC were happening elsewhere such as in Europe. We seek to understand the historical dynamics of IC's past and the lessons it might have for 21st century educators. We end by exploring the emerging global rationale for IC in a 21st century context.

The long and distinguished history of IC has been largely ignored (Beane, 1997; Wraga, 1997; Humes, 2013). This history involves an understanding of traditional and progressive education. 
Philosophically and practically, each takes a fundamentally different view of teaching and learning. Within themselves, the terms "traditional" and "progressive" encompass diverse interpretations.

The goal of the traditional approach is to pass on the inherited knowledge of society. The traditional paradigm organizes knowledge into defined disciplines reaching back centuries. The teacher's role as a subject expert is to support students' acquisition of disciplinary knowledge, most often through the transmission model with the help of an authoritative textbook. Memorization and rote learning are key strategies; students demonstrate their learning through correct answers on standardized and common tests. The traditional model is well entrenched, and continues to thrive worldwide (Adolfsson, 2018).

A progressive curriculum strives to develop skills and dispositions so that students may realize their individual personhood and contribute to the improvement of society as engaged citizens. Because of the diversity of views and practices, even the Progressive Education Association (PEA) struggled to define "progressive" (Kridel and Bullough, 2002), but there is general agreement about its spirit. Rather than as passive receivers of knowledge, this student-centered approach sees students as active constructors and interpreters of knowledge. Thus, problem-solving and critical thinking are two of a constellation of cognitive skills foregrounded by a progressive approach. Although there is no blueprint, inquiry arising from student interest is a key component. Progressive educators are concerned with students becoming good learners but also good people; progressive curriculum builds on community, collaboration, social justice, deep understanding of real-world problems and active learning (Kohn, 2008).

Curriculum integration and progressivism should not be conflated; indeed, progressive educators need not adopt IC. Nevertheless, teachers attracted to IC are usually predisposed to a progressive approach, and the history of IC is closely tied to progressivist education (Applebee et al., 2003).

\section{DEFINING INTEGRATED CURRICULUM}

The ambiguity of definitions for IC has troubled researchers and hindered practitioner understanding (Klein, 1990; Czerniak et al., 1999; Pang and Good, 2000; Hurley, 2001; Lenoir and Hasni, 2010). For some, integration within the subject areas itself or intradisciplinary curriculum is considered to be IC. For example, science would be taught as a general science rather than as biology, physics, and chemistry. Fusion is another low level integration in which something is fused into different subject areas. For example, environmental stewardship or peace education or a 21 st century skill such as creativity could be infused into all subjects and all grades. For many researchers, IC can be described as falling on a continuum as in Figure 1 where the degree of integration increases.

A multidisciplinary curriculum is more integrated. Content, instruction and assessment are specific to each discipline. However, the disciplines share a common theme or concept such as "water." Students study the topic or theme through the separate lens of each subject. Connections among disciplines may or may not be made explicit by the various disciplinary teachers or at learning centers with one teacher.

In an interdisciplinary curriculum, disciplines remain somewhat distinct, but their connections are stronger and made explicit. Boundaries are blurred when subjects are organized around a key interdisciplinary concept such as sustainability, or around complex interdisciplinary skills such as critical thinking or competencies such as intercultural competency. Interdisciplinary projects provide a context for the exploration and blending of the subjects. Often interdisciplinary team members share instruction and assessment to ensure that disciplinary standards are met. A transdisciplinary curriculum is the most integrated model. Students begin with an authentic real-world issue rather than with the disciplines. Students' own interests often generate the starting point. For example, they may wish to explore solutions to the problem of traffic congestion in their city using many different disciplinary perspectives. Some versions of project-based learning (PBL) fall into the transdisciplinary realm.

Seeing IC as a continuum may be a useful way of demonstrating its variety of form, and it might describe stages of professional development that educators go through as they experiment with increasing degrees of integration (Brazee and Cappelluti, 1995; Bergstrom, 1998; Snapp, 2006). However, presenting integration as a continuum in any form has raised concerns. One objection is that a continuum could imply an inappropriate hierarchy: more progressive than, more innovative than, better than (Chrysostomou, 2004; Rennie et al., 2012). Another is that a continuum oversimplifies the complexity of IC and ignores its history (Hargreaves et al., 1996; Dowden, 2007, 2011). Beane (1997) viewed his "integrative" model (what we would describe as "transdisciplinary") as the only truly integrated one. He and Hopkins $(1935,1937)$ perceived models on the continuum to be only a rearrangement of subject areas and without acknowledging the centrality of the students and the broader social purposes of progressivism (Dowden, 2007).

The next section of this article considers the historical conceptions and implementation of IC over the last 100 years.

\section{PAST ITERATIONS OF INTEGRATED CURRICULUM}

\section{Foundations of Progressive Education in United States}

The history of IC is linked to the progressive movement of the 1930s and beyond (Wrightstone, 1935; Klein, 1990; Beane, 1991; Vars, 1991). One of the main tenets of progressive education was that knowledge was not bound by disciplines. As Dewey said in 1900, "Relate the school to life and all studies are of necessity correlated" (Dewey, 1915/1900, p. 32).

The term "integrated curriculum" was not used formally until 1931, but the antecedents for the concept were emerging long before this. The seeds of progressive education were planted by Colonel Francis Parker whose school offered a dramatically 


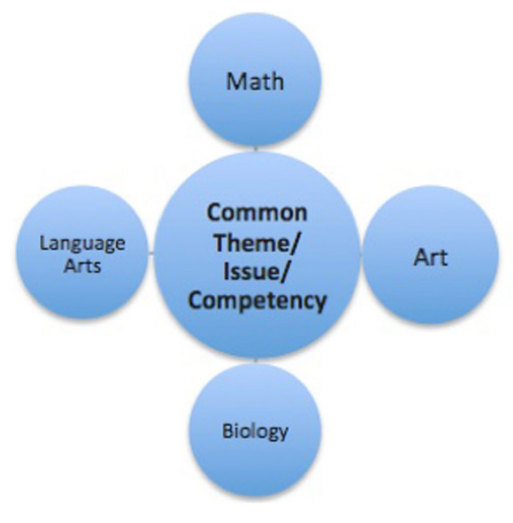

Multidisciplinary

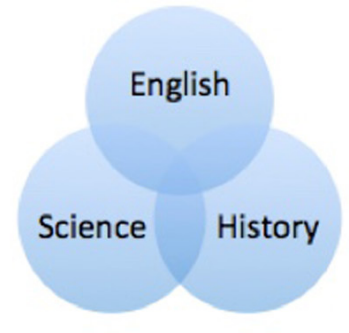

Interdisciplinary

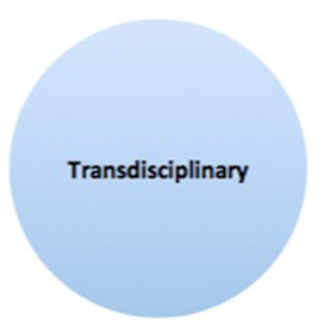

Transdisciplinary

FIGURE 1 | An example of a continuum of integration.

different approach to teaching, learning, and assessing. He emphasized teaching for mental, physical, and moral growth of the whole person (Cooke, 2005). Parker promoted collaborative group learning, student-centered activities, and no testing.

John Dewey, considered the father of the American progressive education movement, encouraged curriculum based on inquiry. Rather than beginning with disciplines, curriculum should begin with students' questions. These should be answered by applying systematic problem-solving procedures-the scientific method-that would connect to a real-world understanding of the disciplines (Dewey, 1938/1993). Dewey (1916) believed in social integration and that the purpose of education was to cultivate a democratic society.

In 1918, Dewey's student William Kilpatrick published The Project Method (Kilpatrick, 1918). Kilpatrick argued that students should apply a problem-solving method to integrate academic, moral and ethical learnings in order to complete a complex purposeful project. Because the project was personally relevant to the student, learning would be lasting and meaningful compared to the transient memorization required by the traditional model.

By the 1930s, the term "integrated curriculum" had become meaningful and loosely associated with the progressive movement. Initially, integration was deemed acceptable for elementary school education only, until Wrightstone (1935) challenged this view. He closely matched 180 students in Grades 4 to 6 who went to either a traditional subject-based school or a progressive school with a unified curriculum. He found that "The pupils in the new type schools were slightly superior in achievement to the pupils in the standard-type schools" (p. 586) on achievement tests in reading, language and arithmetic, indicating that an integrated approach did not jeopardize academic success. The results of Wrightstone's study would be mirrored by the Eight-year Study of the same era.

\section{3-1941 the Eight-Year Study}

The interest in fostering and sustaining the ideals of a democratic society found fertile ground in the project that became known as the Eight-year Study. Curriculum scholar Pinar (2010) wrote that "this remarkable undertaking remains today as perhaps the major school-based curriculum research project in the history of U.S. curriculum studies" (p. 295).

The Great Depression (1928-1939) had resulted in high unemployment and an enormous increase of high school students. There were three types of students: $20 \%$ in a college preparatory program, $20 \%$ in a vocational program, and $60 \%$ non-college bound students who needed "life-adjustment education, to adjust them to life in general" (Tyler, 1989, p. 194). To address this new situation, the Eight-year Study was conceptualized by the PEA and funded with over a million dollars by the Rockerfeller, Carnegie, and other foundations. Widely respected educator Ralph Tyler headed the evaluation team. The Eight-year Study had two aims: (i) to create programs that would be relevant for the $60 \%$ of non-college bound students and "to find, through exploration and experimentation, how the high school in the United States can serve youth more effectively" and (ii) "to establish the relationship between school and college that would permit and encourage reconstruction in the secondary school" without risking students' chances of college acceptance (Aikin, 1942, p. 116).

According to Tyler (1989), more than 30 schools, including two school systems, from across the United States took part. Schools were rural and urban, large and small, private and public. The teachers were no less variable. The common thread was the commitment to enact the progressive principles even though educators could not agree on what those were (Kridel and Bullough, 2002, p. 69). With no prescribed curriculum, teachers were free to innovate in ways that they believed best served students. Key principles grounded their work. Lessons needed to be personally meaningful and involve the whole person. Students needed to develop a social awareness and learn experientially how to be citizens in a democratic society. To varying degrees, the Eight-year Study schools emphasized student-centered learning that incorporated the hallmark aspects of progressive education: hands-on learning, valuing diversity, 
coherent/integrated curriculum, inquiry and problem solving, critical thinking, collaboration, taking social responsibility, community engagement, and democratic values (Lipka et al., 1998; Kridel and Bullough, 2002, 2007; Bullough and Kridel, 2003).

Some schools were cautious in exploiting their new freedom and not all schools adopted an integrated approach. However, the more innovative schools organized curriculum around themes and issues relevant to students. Aikin (1942) provided an extensive list of topics grouped under broad categories such as personal living, social-civic relationships, and economic relationships. In one classroom, the student could learn how to appreciate art, improve one's poise, and analyze sources of information that influence public opinion (Aikin, 1942, pp. 58-61).

How did students fare under the study? Extensive data were collected including achievement on standardized tests, student interest inventories and psychological tests (Kridel and Bullough, 2002; Kridel, 2010). Data indicated that the Eight-year students were not handicapped by their innovative curricula (Aikin, 1942, p, 117). A further follow-up study investigated college achievement. Success was determined by comparing 1,475 matched pairs on 18 variables. Students from the Eight-year Study schools performed academically as well as, or better than, their counterparts from traditional programs. The Eight-year students outperformed their counterparts in time management, resourcefulness, problem-solving, degree of intellectual curiosity, drive, and active concern for world events. As well, "the experimental group was also fully as effective in their employment" (Tyler, 1989, p. 198). Student records from the six most experimental schools that actually implemented IC were compared with student records from traditional schools. The 323 experimental students substantially outperformed their peers on virtually all measures of college success (Kridel, 2010).

Watras (2006) listed several factors that contributed to the decline of progressivism: closure of some participating schools, leadership and staff turnover, lack of professional development and resources, and the rise of a more conservative attitude in the face of war. Beane (1997) also added that many teachers were frightened by this approach. However, the Eight-year Study and progressivism had a lasting impact on subsequent decades (Kridel, 1998).

\section{0s and 1950s Core Curriculum - The Salad Days}

Integrated Curriculum did continue into the 1940s and 1950s. It was most frequently identified as general education, unified or core. "In retrospect, these were the salad days of curriculum integration" (Beane, 1997, p. 29). Core programs proliferated across the United States. Beane (1997) claimed that over 50\% of junior and senior high schools were involved in block-time non-separate subject approaches programs, although problemcentered programs were less common.

The Virginia Curriculum Revision Program from 1932 to 1952 is one example of the era's large-scale IC effort (Kliebard, 1995; Dowden, 2007). In 1931, Hollis Caswell introduced curriculum planning on a matrix. The vertical axis identified cultural values and aspects of everyday life that replaced disciplines. The horizontal axis identified themes of student interest. In 1937, when $85 \%$ of Virginia's teachers were implementing this program, the state surveyed teachers and parents and collected achievement data. The program was considered a "great improvement" in elementary schools over the discipline-based curriculum used previously. However, there was less enthusiasm for it in the high schools which Caswell blamed on the resistance of teachers to change from subject specialists to core teachers.

Mickelson (1957) summarized several studies comparing achievement of core curriculum students to that of students in traditional programs. The studies considered academic achievement as well as social attitudes and behaviors. The findings replicated those of the Eight-year Study. Thus, Mickleson concluded that "the most promising educational development for meeting the needs of adolescents today is the core curriculum" (p. 158).

Despite its popularity and evidence of its effectiveness, core programs faded into obscurity in the 1960s in the wake of the Cold War competition for scientific and technological superiority. Innovation was sacrificed to a fearful retreat to conventional disciplinary structures (Wraga, 1992, 1997; Watras, 2006). Bruner's (1960) The Process of Education ensured that disciplinary organization was optimal for learning. By the 1970s, Bruner (1971) had reversed his position, preferring a curriculum grounded in contemporary problems, but it was too late. There were few ventures into integrated territory until the 1980s and 1990s.

\section{0s and 1990s-The Wild Frontier}

A concern for relevancy and low student engagement in the 1980s and early 1990s prompted a resurgence of interest in IC. The influential Carnegie Report (1989) and the California State Department of Education Report (1987) reported that middle school students were unmotivated and that alternatives to the disciplinary organization should be implemented. Emerging brain research indicated that people learn better by making connections rather than by memorization (see, e.g., Sylwester, 1995; Caine and Caine, 1997). In addition, digital technology and the Internet were changing the world. The U.S. Department of Labor (1991) identified the skills needed for the future: literacy, basic computation, creative thinking, learning how to learn, and decision-making. Productive citizens would need the interdisciplinary life skills required by the changing workplace. Although the context was different, this need was similar to the life skills students needed in the progressive era.

State education departments began exploring IC and providing professional development for eager teachers. Dissemination was multi-pronged and lively through major national conferences, whole issues of popular publications (e.g., Education Leadership, Volume 49, Issue 2, 1991), and influential experts such as Jacobs (1989), Fogarty (1991), Drake (1993, 1998), and Kovalic (1994). The atmosphere was vibrant, but rather incoherent.

Erickson $(1995,2008)$ advocated designing IC through Big Ideas in the form of broad-based concepts rather than factual 
content, and interdisciplinary rather than disciplinary skills. For her, a concept-based curriculum assured depth. Erickson's work was grounded in the work of Taba (1962). Their ideas remain central to 21 st century curriculum planning.

Most variations of IC were based on a progressive/constructivist philosophy with a focus on student inquiry and choice, collaborative work, and the teacher as a facilitator. As a summative assessment, most iterations added a rich performance assessment task which could be likened to Kilpatrick's project method.

The Humanitas project is just one of many examples of an interdisciplinary program that flourished in this period. Implemented in various schools, Humanitas was theme-based (e.g., Making a Place for All: The Immigrant Experience) and used a collaborative team-teaching approach. The program emphasized conceptual development, critical thinking, and communication skills. Humanitas was evaluated by UCLA's Center for the Study of Evaluation which found that Humanitas students were stronger conceptual thinkers and communicators than their peers from traditional programs (Aschbacher, 1991).

Beane (1997) believed, like his progressive antecedents, that students should design their own curriculum with their teachers. Beane advocated that curriculum should start with students' answers to the questions: What questions and concerns do you have about yourself, and what questions and concerns do you have about your world? Such questions are reminiscent of those that inspired curriculum under the Eight-year Study.

In the closing decades of the 20th century, IC was evident in various curriculum experiments such as team teaching, block scheduling, and student activities (Vars, 1991). There was an abundance of research at this time but much of it was anecdotal from enthusiastic teachers or revolved around confusion about definitions or were descriptive "how-to" articles. There was no large-scale study such as the Eight-year Study to support IC's implementation in the evidence-based environment. Vars and Beane (2001) summed up the research of the 1980s and 1990s with this now-repetitive refrain:

\begin{abstract}
Almost without exception, students in any type of interdisciplinary or integrative curriculum do as well as, and often better than, students in a conventional departmentalized program. These results hold whether the combined curriculum is taught by one teacher in a self-contained or block-time class or by an interdisciplinary team ${ }^{1}$.
\end{abstract}

Ignorant of history, many practitioners were reinventing the wheel, each in their own ways, to address the immediate issue of student apathy and a knowledge explosion. Missing was a coherent vision grounded in deep understanding of shared principles. For Wraga $(1992,1997)$, a factor was the failure of the models to draw from past initiatives.

The heady days of IC came to an end. The positive advantages of more engaged students and re-energized teachers were offset by the lack of solid research, territorial wars among subject

\footnotetext{
${ }^{1}$ http://www.ericdigests.org/2001-1/curriculum.html
}

organizations, logistical difficulties such as scheduling, and parental longing for the standardized reporting they understood.

A more powerful movement sounded IC's death knell. The age of accountability took hold across the globe. Standardized testing refocused attention on the basic subjects of literacy, math, and science (Lam et al., 2013). Educational jurisdictions developed disciplinary standards (competencies, expectations, capabilities, outcomes). Pacer guides shaped practice. Big data allowed for comparisons among students, classes, schools, regions, states, and internationally. A new era had begun, and silence descended around IC.

\section{1st CENTURY CURRICULUM}

OECD captured the mood of the early decades of the 21 st century.

\begin{abstract}
We are facing unprecedented challenges...driven by accelerating globalization and a faster rate of technological developments... The future is uncertain... Schools can prepare [students] for jobs that have not yet been created, for technologies that have not yet been invented, to solve problems that have not yet been anticipated... Students will need to develop curiosity, imagination, resilience and self-regulation; they will need to respect and appreciate the ideas, perspectives and values of others... Their motivation will be more than getting a good job...They will also need to care about the well-being of their friends and families, their communities and the planet. Education can equip learners with agency and a sense of purpose, and the competencies they need, to shape their own lives and contribute to the lives of others (OECD, 2018, p. 2).
\end{abstract}

\section{Current Drivers of IC}

Alongside the accountability agenda inherited from the 1990s came an international call for educational reforms that could deepen learning and address the complexity, disruptions, and fast-changing technologies of the new century (Hargreaves and Shirley, 2009; Hattie, 2012; Fullan, 2013). Inquiry-based, projectbased/problem-based learning and IC were and continue to be pedagogies put forward to meet the challenges of relevancy.

There are multiple drivers encouraging educators to reconsider IC in the 21st century. One is the re-conception of knowledge and an international rethinking about what is worth knowing. Siri and Google have made the memorization of disciplinary content obsolete. Internet research on a topic such as war will yield interdisciplinary results. The real world is not bounded by disciplines. A knowledge base in the disciplines is not enough. The learning and life skills of the 1930s, 1980s, and 1990s have been revived in frameworks for 21st century skills/competencies.

There is growing international consensus on the importance and the definition of the competencies of 21st-century learning (OECD, 2005, 2017; EU, 2006; Dede, 2010; Voogt and Roblin, 2012; Brooks and Holmes, 2014; Partnership for 21st century skills, 2015; New Zealand Ministry of Education, n.d.). These include critical thinking, communication, collaboration, problem solving, creativity, character education/ethics and citizenship, intercultural competency, global awareness, agility/adaptability, as well as computer and digital technological capability 
(Ananiadou and Claro, 2009; Fullan and Langworthy, 2013; Howard et al., 2019).

A second driver of IC is global wicked problems. The concept of problem-solving has broadened beyond its pre-21st century roots. A wicked problem is ill-structured, ambiguous (Rittel and Webber, 1973) and almost impossible to solve (Klein, 2004, 2014; Nicolescu, 2010). The coronavirus pandemic with its tangled and interconnected health, economic, privacy/surveillance and social justice consequences is such a problem. Solutions, if they exist, are transdisciplinary. Students need experience in transdisciplinary problem-solving to be equipped to live with "wickedness" of the 21 st century context.

A third driver is the recurring issue of engagement. Surveys have reported student disengagement (Gallup, 2014; Jasperson, 2014). IC increases student engagement (Lattuca et al., 2004; Alexander et al., 2008; Catterall et al., 2012; Guthrie et al., 2013; Lam et al., 2013).

IC engages teachers too. Despite initial struggles moving out of their disciplinary comfort zone (Gunn and King, 2003; Smithrin and Upitis, 2005; Applebee et al., 2007; Fenwick et al., 2013), teachers come to appreciate the opportunity to collaborate with colleagues and to explore new subjects and pedagogy (Ching, 2009; Lardner and Malnarich, 2009; Weinberg and Sample McMeeking, 2017). An added bonus is efficiency. In overcrowded and fragmented curricula, IC can provide coherence and reduce duplication (Hinde, 2005; Adolfsson, 2018). The pan-disciplinary competencies listed above offer an amenable way to knit together disciplinary content.

\section{Current Versions of IC}

Versions of IC exist in current trends. Inquiry is a skill that drives most non-traditional curriculum design (Drake et al., 2014). Structured inquiry and experiential learning take us back to the central tenets of progressive education. In the 21st century context, project-based learning (PBL) is a pedagogy that lends itself to an interdisciplinary approach because its underlying philosophy is student-centered, inquiry based, and oriented to big picture concepts and skills applied to real world issues. The Buck Institute for Education ${ }^{2}$ offers rich examples of PBL in the classroom. Similarly, Finland's phenomenon-based learning follows this path (Christou, 2016). Finnish students in Grades 1-9 work on 9-week long, interdisciplinary projects prompted by their own questions (Mathewson, 2019). This is similar to Kilpatrick's project method in 1918. The positive outcomes such as depth of learning, thinking skills, and engagement, achieved through projects are well documented (see Thomas, 2000; Hmelo-Silver et al., 2007; Holm, 2011; Vega, 2012a).

In the United States, many states are using the Common Core State Standards (CCSS) and the Next Generation Science Standards to design curriculum for literacy and numeracy K to 12. The intent of the CCSS is to increase accountability across states and ensure students acquire the skills for life success. Controversial issues such as testing aside, the CCSS actually can be interpreted in ways that encourage IC as illustrated in Creating standards-based integrated curriculum: The

${ }^{2}$ https://www.pblworks.org
Common Core Standards Edition (Drake, 2012). The standards themselves allow for flexibility and can be taught in relevant and creative ways. As well, the CCSS provides literacy standards for history/social studies, science and technical subjects indicating that literacy is the responsibility of teachers of different subject areas not just of the language teachers-a door to IC.

Other ways in which integration occurs include the following: STEM and STEAM (Satchwell and Loepp, 2002; Vega, 2012b; Miller, 2014; MacDonald et al., 2019); the infusion of literacy (Cervetti et al., 2007; Alvermann et al., 2011; Romance and Vitale, 2012a,b; Vega, 2013); the infusion of the arts (Upitis, 2011; Catterall et al., 2012; Riley, 2013); and the infusion of environmental responsibility (Blair, 2009).

\section{Challenges to Implementing IC}

So far, widespread implementation of IC has been hampered by practical and theoretical challenges. These include ambiguity around definitions, issues with measuring interdisciplinary knowledge and behaviors, logistics such as scheduling and reporting protocols, territorial battles, teacher identity as a subject expert, and resistant educators.

Dissenting voices question the prominence of the 21st competencies at the expense of prescribed disciplinary content (Priestley and Sinnema, 2014). A concern is the economic undertone expressed in the rationales for a competency-based curriculum. Critics of this neoliberal view say that in emphasizing students' need for an education that prepares them to compete successfully in the workplace, students become the human capital engines of a nation's GDP (Dede et al., 2005; Adolfsson, 2018).

Another concern is related to equity. Social realists argue for the importance of universal access to the external, objective, authoritative knowledge of established disciplineswhat Young (2010) calls "powerful knowledge" (Young, 2010; Rata, 2012). When curriculum is premised on students' experiential knowledge, the risk of limitation becomes especially acute because it disfavors those with low social and cultural capital. Social realists do not argue for a retrenchment of fixed disciplinary content-a "Future 1" scenario; rather, they propose a "Future 3" scenario that sits between a boundless "Future 2" and an overly-narrow Future 1 (Young and Muller, 2010).

\section{Benefits of IC}

Integrated Curriculum leads to positive learning outcomes and personal development. The literature in the last two decades has arrived at the conclusion we have heard before: students in IC programs perform academically as well as, and sometimes better than, their counterparts from traditional programs (Brough and Pool, 2005; Hinde, 2005; Erickson, 2008; Kelleher, 2008; Rotherham and Willingham, 2009; Drake, 2012; Griffin et al., 2012; Drake and Reid, 2018). As well, a rich body of literature attests to IC's benefits in the affective domain including self-regulation, prosocial attitudes, emotional health, creativity and motivation (see, for example, Cordogan and Stanciak, 2000; Edwards and Willis, 2000; Consortium of National Arts Education Associations, 2002; Marshall, 2005; Trent and Riley, 2009; Kakas, 2010; Durlak et al., 2011; Catterall et al., 2012). 


\section{CONCLUSION}

\section{The Global Conversation as Proxy PEA}

Conditions in the 21st century are ripe for interdisciplinary approaches. In many ways, today's educational reform is reminiscent of the early 1930s. Today, as then, reformers are seeking ways to offer engaging relevant curriculum in an accountable manner. In the 1980s and 1990s, curriculum experts created IC models reflecting their individual personal philosophies. Neither accountability nor a focus on democratic values was a high priority. We suggest that inconsistency resulted because educators did not realize that there were historical precedents and because there was no proxy PEA to provide guidance and coherence.

Today, educators are not guided by history in particular, but rather by an emerging global conversation about curriculum innovation that emphasizes 21st century skills/competencies; we suggest that this conversation can act as a 21 st centuryversion PEA. Indeed, Kamens and McNeely (2009) see the emergence of a "world educational ideology" (p. 9) and Sellar and Lingard (2014) see OECD and its PISA testing as a new epistemological and infrastructure of global governance.

In this global conversation, a consistent vision is emerging. The 21 st century is stimulating a student-centered culture of learning that harkens back to earlier progressive movements. Personalization, technology, and universal design principles are revamping instruction. Assessment practices are shifting in emphasis from external summative testing to localized, formative feedback for improvement. The teacher's role is shifting from content expert to learning facilitator (Dede et al., 2005; Friesen and Jardine, 2014; Partnership for 21st century skills, 2015).

Aligning with the conversation, frameworks from external organizations and educational jurisdictions, in both public and independent contexts, are remarkably alike and go beyond academic achievement to learning how to be and how to be in community. Overarching frameworks focusing on competencies have been developed, for example, by external global networks such as the Center for Curriculum Reform (Fadel et al., 2015) and The World Economic Forum (2016). One of the most influential external organizations is the OECD (Grek, 2009; Kamens and McNeely, 2009; Munch, 2014). Cognitive, health, and social emotions form the foundational umbrella for OECD's (2018) compass for 2030. Along with competencies, the compass references well-being, student agency, and connections with community.

Internationally, many jurisdictional curriculum documents present a unifying framework that acts as an umbrella over all disciplines. The 21st century competencies are infused into every subject and every grade; see, for example, Singapore, South Korea, Finland, Australia, and Alberta (Drake and Savage, 2016). Also evident in these frameworks is an overarching concern for the whole child. For example, Hong Kong's unifying framework calls for perseverance, respect for others, responsibility, self-management, and commitment to be taught across all subject areas in all grades (Drake and Savage, 2016). The International Baccalaureate Organization (2012) has a unifying framework for its transdisciplinary primary program that involves over 4000 independent schools across the globe. This framework is focused on a learner being not only knowledgeable, inquirers, creative and critical thinkers but also reflective, caring, principled, and balanced. New Zealand is integrating local contexts reflecting Indigenous cultures with international competency frameworks (New Zealand Ministry of Education, n.d.).

These frameworks cry for IC in order to weave together their transdisciplinary aspects. The emerging vision is a hopeful work in progress that attempts to reconcile seemingly contradictions through a both/and perspective: both accountability and whole child priorities; both disciplinary and interdisciplinary; both content and skills. IC offers a context to accomplish these resolutions. For example, evidence in this article indicates that academic achievement for students in any era who experience IC has been at least equivalent to, if not better than that of students in traditional programs (accountability), with the bonus of prosocial attitudes, better attendance, internal motivation, and enjoyment of school (whole child).

Little (2013) has said there are lessons for 21st century educators in the recurrence over IC's history of progressive principles. However, he noted that later versions of IC lack the 1930s grounding in social justice and democracy. We suggest that social responsibility and citizenship act as a proxy for the progressive 1930s democracy. Current global frameworks do recognize developing citizenship and national identity in whatever ideology applies to them. These principles-rooted firmly in the past ethical foundations-are not to be forgotten as the global educational networks continue to collaborate and influence curriculum design that reflects both national and global priorities.

For us, the 21 st century context encourages a rethinking of what has been rethought for one hundred years about IC. We urge educators to consider the parallels among past eras and find in them the way forward for future curriculum. As it has in the past, we believe IC presents an engaging, relevant, and effective model for curriculum today.

\section{AUTHOR CONTRIBUTIONS}

SD and JR contributed equally and collaboratively to the research and writing of this work and approved the submitted version.

\section{ACKNOWLEDGMENTS}

We would like to thank the reviewers for encouraging feedback and thoughtful suggestions. 


\section{REFERENCES}

Adolfsson, C.-H. (2018). Upgraded curriculum? An analysis of knowledge boundaries in teaching under the Swedish subject-based curriculum. Curriculum J. 29, 1-17. doi: 10.1080/09585176.2018.1442231

Aikin, W. (1942). The Story of the Eight- Year Study. New York, NY: Harper and Brothers.

Alexander, J., Walsh, P., Jarman, R., and McClune, B. (2008). From rhetoric to reality: advancing literacy by cross-curricular means. Curriculum J. 19, 23-35. doi: 10.1080/09585170801903225

Alvermann, D. E., Achariya, T., Rezak, C. A., Boatright, M. D., and Jackson, D. F. (2011). Reflective practice in an online literacy course: lessons learned from attempts to fuse reading and science instruction. Teach. Coll. Rec. 113, $27-56$.

Ananiadou, K., and Claro, M. (2009). "21st century skills and competences for new millennium learners in OECD Countries," in Proceedings of the OECD Education Working Papers (Paris: OECD Publishing).

Applebee, A. N., Adler, A., and Filhan, S. (2007). Interdisciplinary curricula in middle and high school classrooms: case studies of approaches to curriculum and instruction. Am. Educ. Res. J. 44, 1002-1039. doi: 10.3102/ 0002831207308219

Applebee, A. N., Langer, J. A., Nystrand, M., and Gamoran, A. (2003). Discussionbased approaches to developing understanding: classroom instruction and student performance in middle and high school English. Am. Educ. Res. J. 40, 685-730. doi: $10.3102 / 00028312040003685$

Aschbacher, P. R. (1991). Humanitas: a thematic curriculum. Educ. Leadersh. 49, $16-19$.

Beane, J. (1991). The middle school: the natural home of integration. Educ. Leadersh. 49, 9-13.

Beane, J. A. (1997). Curriculum Integration. Designing the Core of Democratic Education. New York, NY: Teachers College Press.

Bergstrom, K. L. (1998). Are we missing the point about curriculum integration? Middle Sch. J. 29, 28-37. doi: 10.1080/00940771.1998.11495319

Blair, D. (2009). The child in the garden: an evaluative review of the benefits of school gardening. J. Environ. Educ. 40, 15-38. doi: 10.3200/joee.40.2. 15-38

Brazee, E. N., and Cappelluti, J. (1995). Dissolving Boundaries: Toward Integrative Curriculum. Columbus, OH: National Middle School Association.

Brooks, M., and Holmes, B. (2014). Equinox Blueprint Learning 2030. A Report on the Outcomes of the Equinox Summit Learning 2030. Waterloo: Waterloo Global Science Initiative.

Brough, J. A., and Pool, J. E. (2005). "Integrating learning and assessment: The development of an assessment culture," in Curriculum Integration K-12: Theory and Practice, ed. J. E. Etim (Lanham, MD: University Press of America), 196-204.

Bruner, J. (1960). The Process of Education. Cambridge, MA: Harvard University Press.

Bruner, J. (1971). "The process of education reconsidered," in Dare to Care/Dare to Act, ed. R. R. Leeper (Washington, DC: ASCD), 19-30.

Bullough, R. V., and Kridel, C. (2003). Adolescent needs, curriculum and the Eight-Year Study. J. Curr. Stud. 35, 151-169.

Caine, R., and Caine, G. (1997). Education on the Edge of Possibility. Alexandria, VA: ASCD.

California State Department of Education Report (1987). Caught in the Middle: Educational Reform for Young Adolescents in California Public Schools. Sacramento, CA: Author.

Carnegie Report. (1989). Turning Points: Preparing American Youth for the 21st Century. The Report of the Task Force on Education of Young Adolescents. New York, NY: Author.

Catterall, J. S., Dumais, S. A., and Hampden-Thompson, G. (2012). The Arts and Achievement in At-Risk Youth: Findings from Four Longitudinal Studies. National Endowment for the Arts Research Report \#55. Los Angeles, CA: University of California Los Angeles.

Cervetti, G. N., Pearson, P. D., Barber, J., Hiebert, E. H., and Bravo, M. S. (2007). "Integrating literacy and science: the research we have and the research we need," in Shaping Literacy Achievement: Research We Have, the Research We Need, eds M. Pressley, A. K. Billman, K. H. Perry, K. E. Refitt, and J. M. Reynolds (New York, NY: The Guilford Press), 157-174.
Ching, G. S. (2009). Implications of an experimental information technology curriculum for elementary students. Comput. Educ. 53, 419-428. doi: 10.1016/ j.compedu.2009.02.019

Christou, T. M. (2016). 21st-century learning, educational reform, and tradition: Conceptualizing professional development in a progressive age. Teach. Learn. Prof. Dev. 1, 61-72.

Chrysostomou, S. (2004). Interdisciplinary approaches in the new curriculum in Greece: a focus on music education. Arts Educ. Policy Rev. 105, 23-30. doi: 10.3200/aepr.105.5.23-30

Consortium of National Arts Education Associations (2002). Authentic Connections: Interdisciplinary Work in the Arts. Reston, VA: National Art Education Association.

Cooke, F. (2005). Colonel Francis W. Parker: his influence on education. Schools 2, 157-170. doi: $10.1086 / 589166$

Cordogan, S., and Stanciak, L. (2000). "An examination of the effects of an interdisciplinary curriculum program on behavior and academic performance in a suburban high school (A compilation of the first three years of a four-year study)," in Paper Presented at the Annual Meeting of the American Educational Research Association, New Orleans, LA.

Czerniak, C., Weber, W. B., Sandmann, A., and Ahern, J. (1999). A literature review of science and mathematics integration. Sch. Sci. Math. 99, 421-430. doi: 10.1111/j.1949-8594.1999.tb17504.x

Dede, C. (2010). "Comparing frameworks for 21st century skills," in 21st Century Skills: Rethinking How Students Learn, eds J. Bellance, and R. Brandt (Bloomington, IN: Solution Tree Press), 20, 51-76.

Dede, C., Korte, S., Nelson, R., Valdez, G., and Ward, D. (2005). Transforming Education for the 21st Century: An Economic Imperative. Chicago, IL: Learning Point Associates.

Dewey, J. (1916). Democracy and Education. New York, NY: MacMillan.

Dewey, J. (1938/1993). Experience and Education. New York, NY: MacMillan.

Dewey, J. (1915/1900). The School and Society (rev edition). Chicago, IL: University of Chicago Press.

Dowden, T. (2007). Relevant, challenging, integrative and exploratory curriculum design: perspectives from theory and practice for middle level schooling in Australia. Aust. Educ. Res. 34, 51-71. doi: 10.1007/bf03216857

Dowden, T. (2011). Locating curriculum integration within the historical context: Innovations in Aotearoa New Zealand State Schools, 1920s-1940s. Hist. Educ. Rev. 40, 47-61. doi: 10.1108/08198691111140802

Drake, S. M. (1993). Planning Integrated Curriculum: The Call to Adventure. Alexandria, VA: ASCD.

Drake, S. M. (1998). Creating Integrated Curriculum: Proven Ways to Increase Student Success. Thousand Oaks, CA: Corwin press.

Drake, S. M. (2012). Creating Standards-Based Integrated Curriculum: Common Core State Standards Edition, 3nd Edn. Thousand Oaks, CA: Corwin.

Drake, S. M., and Reid, J. L. (2018). Integrated curriculum as an effective way to teach 21st Century capabilities. Asia Pac. J. Educ. Res. 1, 31-50. doi: 10.30777/ apjer.2018.1.1.03

Drake, S. M., Reid, J. L., and Kolohon, W. (2014). Interweaving Curriculum and Classroom Assessment: Engaging the 21st Century Learner. Toronto, ON: Oxford University Press.

Drake, S. M., and Savage, M. (2016). Negotiating accountability and integrated curriculum from a global perspective. Int. J. Learn. Teach. Educ. Res. 15, 127-144.

Durlak, J., Weissberg, R. P., Dymnicki, A. B., Taylor, R. D., and Schellinger, K. B. (2011). The impact of enhancing students' social and emotional learning: a meta-analysis of school-based universal interventions. Child Dev. 82, 405-432. doi: 10.1111/j.1467-8624.2010.01564.x

Edwards, C. P., and Willis, L. M. (2000). Integrating visual and verbal literacies in the early childhood classroom. Early Child. Educ. J. 27, 259-265. doi: 10.1023/b: ecej.0000003364.99437.5d

Erickson, L. (1995). Stirring the Head, Heart and Soul: Redefining Curriculum, Instruction and Concept-Based Learning. Thousand Oaks, CA: Corwin.

Erickson, L. (2008). Stirring the Head, Heart and Soul: Redefining Curriculum, Instruction and Concept-Based Learning, 3rd Edn. Thousand Oaks, CA: Corwin.

EU (2006). Recommendations of the European Parliament and of the Council of 18 December 2006 on Key Competences for Lifelong Learning. (2006/962/EC). Available online at: https://eur-lex.europa.eu/legal-content/EN/TXT/?uri= celex\%3A32006H0962 (accessed June 30, 2020). 
Fadel, C., Bialik, M., and Trilling, B. (2015). Four-Dimensional Education: The Competencies Learners Need to Succeed. Center for Curriculum Redesign. Available online at: https://curriculumredesign.org/our-work/fourdimensional-21st-century-education-learning-competencies-future-2030/ (accessed June 30, 2020).

Fenwick, A. J. J., Minty, S., and Priestley, M. (2013). Swimming against the tide: a case study of an integrated social studies department. Curriculum J. 24, 454-474. doi: 10.1080/09585176.2013.805658

Fogarty, R. (1991). Ten ways to integrate curriculum. Educ. Leadersh. 47, 61-65.

Friesen, S., and Jardine, D. (2014). "21st century learning and learners," in Prepared for the Western and Northern Curriculum Protocol by Galileo Educational Network. Calgary: University of Calgary.

Fullan, M. (2013). Great to Excellent: Launching the Next Stage of Ontario's Education Agenda. Available online at: https://www.michaelfullan.ca/wpcontent/uploads/2013/09/13_Fullan_Great-to-Excellent.pdf (accessed June 30, 2020).

Fullan, M., and Langworthy, M. (2013). Towards a New End: New Pedagogies for Deep Learning. Seattle, WA: Collaborative Impact.

Gallup (2014). The State of America's Schools The Path to Winning Again in Education. Available online at: https://www.gallup.com/education/269648/ state-america-schools-report.aspx (accessed June 30, 2020).

Grek, S. (2009). Governing by numbers: the PISA 'Effect' in Europe. J. Educ. Policy 24, 23-37. doi: 10.1080/02680930802412669

Griffin, P. E., McGaw, B., and Care, E. (eds) (2012). Assessment and Teaching of 21st Century Skills (ATC21S). Dordrecht: Springer.

Gunn, J. H., and King, M. B. (2003). Trouble in paradise Power, conflict, and community in an interdisciplinary teaching team. Urban Educ. 28, 173-195. doi: $10.1177 / 0042085902250466$

Guthrie, J. T., Klauda, S. L., and Ho, A. N. (2013). Modeling the relationships among reading, instruction, motivation, engagement and achievement for adolescents. Read. Res. Q. 48, 9-26. doi: 10.1002/rrq.035

Hargreaves, A., Earl, L., and Ryan, J. (1996). Schooling for Change: Reinventing Education for Early Adolescents. London: Falmer.

Hargreaves, A., and Shirley, D. (eds) (2009). The Fourth Way: The Inspiring Future for Educational Change. Thousand Oaks, CA: Corwin.

Hattie, J. (2012). Visible Learning for Teachers: Maximizing Impact on Learning. New York, NY: Routledge.

Hinde, E. R. (2005). Revisiting curriculum integration: a fresh look at an old idea. Soc. Stud. 96, 105-111. doi: 10.3200/tsss.96.3.105-111

Hmelo-Silver, C. E., Duncan, R. G., and Chinn, C. A. (2007). Scaffolding and achievement in problem-based and inquiry learning: a response to Kirschner, Sweller, and Clark (2006). Response 42, 99-107. doi: 10.1080/ 00461520701263368

Holm, M. (2011). Project-based instruction: a review of the literature on the effectiveness of it in prekindergarten through 12th grade classrooms. Insight 7 , $1-13$.

Hopkins, T. L. (1935). Arguments favoring education. Teach. Coll. 36, 604-612.

Hopkins, T. L. (1937). Integration: Its Meaning and Application. New York, NY: Appleton-Century.

Howard, P., O'Brien, C., Kay, B., and O'Rourke, K. (2019). Leading educational change in the 21st century: creating living schools through shared vision and transformative governance. Sustainability 11:4109. doi: 10.3390/su11154109

Humes, W. (2013). Curriculum for excellence: interdisciplinary learning. Scott. Educ. Rev. 45, 82-93.

Hurley, M. (2001). Reviewing integrated science and mathematics The search for evidence and definition from new perspectives. Sch. Sci. Math. 101, 259-268. doi: 10.1111/j.1949-8594.2001.tb18028.x

International Baccalaureate Organization (2012). What is an IB Education? Cardiff: International Baccalaureate Organization.

Jacobs, H. H. (1989). Interdisciplinary Curriculum: Design and Implementation. Alexandria, VA: ASCD.

Jasperson, P. (2014). In Australia, Student Engagement Dips with Each Year in School. [The Gallup Blog]. Available online at: https://news.gallup.com/opinion/ gallup/175085/australia-student-engagement-dips-year-school.aspx (accessed June 30, 2020).

Kakas, K. (2010). Using drawing with an American urban 6th grade class to enhance learning of an interdisciplinary social studies curriculum. Int. J. Interdiscip. Soc. Sci. 4, 75-82. doi: 10.18848/1833-1882/cgp/v04i12/53053
Kamens, D. H., and McNeely, C. L. (2009). Globalization and the growth of international educational testing and national assessment. Comp. Educ. Rev. 54, 5-25. doi: 10.1086/648471

Kelleher, J. (2008). "Interdisciplinary assessment: a system at the heart of teaching and learning across domains," in Interdisciplinary Education in an Age of Assessment, eds D. M. Moss, T. A. Osborn, and D. Kaufman (New York, NY: Routledge), 155-177.

Kilpatrick, W. H. (1918). The project method. Teach. Coll. Rec. 19, 319-335.

Klein, J. (2004). Prospects for transdisciplinarity. Futures 36, 515-526. doi: 10. 1016/j.futures.2003.10.007

Klein, J. (2014). Discourse of transdisciplinarity: looking back to the future. Futures 63, 68-74. doi: 10.1016/j.futures.2014.08.008

Klein, J. T. (1990). Interdisciplinarity: History. Theory and Practice. Detroit, MI: Wayne State University Press.

Kliebard, H. M. (1995). The Struggle for the American Curriculum 1893-1958, 2nd Edn. New York, NY: Routledge and Paul.

Kohn, A. (2008). Progressive Education. Why it's Hard to Beat and Hard to find. Independent School. Spring. Available online at: https://www.alfiekohn.org/ article/progressive-education/ (accessed June 30, 2020).

Kovalic, S. (1994). ITI-The Model - Integrated Thematic Instruction, 3rd Edn. Kent, WA: Books for Education.

Kridel, C. (1998). The Eight-Year Study Revisited: Lessons from the Past for the Present. Westerville, OH: National Middle School Association.

Kridel, C. (ed.) (2010). Encyclopedia of Curriculum Studies. Thousand Oaks, CA: Sage. doi: 10.4135/9781412958806.n181

Kridel, C., and Bullough, R. V. (2002). Conceptions and misperceptions of the eight-year study. J. Curriculum Supervis. 18, 63-82.

Kridel, C., and Bullough, R. V. (2007). Stories of the Eight-Year Study: ReExamining Education in America. Albany, NY: State University of New York Press.

Lam, C. C., Alviar-Martin, T., Adler, S. A., and Sim, J. B.-Y. (2013). Curriculum integration in Singapore: teachers' perspectives and practice. Teach. Teach. Educ. 31, 23-34. doi: 10.1016/j.tate.2012.11.004

Lardner, E., and Malnarich, G. (2009). When faculty assess integrative learning Faculty inquiry to improve learning community practice. Change 29-35. doi: 10.3200/chng.41.5.28-37

Lattuca, L. R., Voigt, L. J., and Fath, K. Q. (2004). Does interdisciplinarity promote learning? Theoretical support and researchable questions. Rev. High. Educ. 28, 23-48. doi: $10.1353 /$ rhe.2004.0028

Lenoir, Y., and Hasni, A. (2010). Interdisciplinarity in Quebec schools: 40 years of problematic implementation. Issues Integr. Stud. 28, 238-294.

Lipka, R. P., Lounsbury, J. H., Toepfer, C. F. Jr., Vars, G. F., and Alessi, S. P. Jr. (1998). The Eight-Year Study Revisited: Lessons from the Past for the Present. Westerville, OH: National Middle School Association.

Little, T. (2013). 21st Century learning and progressive education. Int. J. Prog. Educ. 9, 84-96.

MacDonald, A., Hunter, J., Wise, K., and Fraser, S. (2019). STEM and STEAM and the spaces between: an overview of education agendas pertaining to 'disciplinarity' across three Australian states. J. Res. STEM Educ. 5, 75-92.

Marshall, J. (2005). Connecting art, learning, and creativity: a case for curriculum integration. Stud. Art Educ. 46, 227-241. doi: 10.1080/00393541.2005.11650076

Mathewson, T. G. (2019). The Teacher's Role in Finland's PhenomenonBased Learning. The Hechinger Report (December 5). Available online at: https://www.kqed.org/mindshift/55006/the-teachers-role-in-finlandsphenomenon-based-learning (accessed June 30, 2020).

Mickelson, J. M. (1957). What does research say about the effectiveness of the core curriculum? Sch. Rev. 65, 144-160. doi: 10.1086/442386

Miller, A. (2014). PBL and STEAM Education: A Natural Fit. Edutopia. Available online at: https://www.edutopia.org/blog/pbl-and-steam-natural-fit-andrewmiller (accessed June 30, 2020).

Munch, R. (2014). Education under the regime of PISA and Co.: Global standards and local traditions in conflict-The case of Germany. Teach. Coll. Rec. 116, 1-16.

New Zealand Ministry of Education (n.d.). The New Zealand Curriculum Online. Available online at: http://nzcurriculum.tki.org.nz/Key-competencies (accessed June 30, 2020).

Nicolescu, B. (2010). Methodology of transdisciplinarity - levels of reality, logic of the included middle and complexity. Transdiscip. J. Eng. Sci. 1, 19-38. 
OECD (2005). The Definition and Selection of Key Competencies. [Executive Summary]. Paris: OECD.

OECD (2017). Education 2030. Paris: OECD.

OECD (2018). The Future We Want. The Future of Education and Skills Education 2030. Paris: OECD.

Pang, J., and Good, R. (2000). A review of the integration of science and mathematics: implications for further research. Sch. Sci. Math. 100, 72-82.

Partnership for 21st century skills (2015). Framework for 21st Century Learning. Available online at: http://slacca.pbworks.com/f/Framework+for+ 21st+Century+Learning+Overview.pdf (accessed June 30, 2020).

Pinar, W. F. (2010). The eight-year study. Curriculum Inq. 40, 295-316.

Priestley, M., and Sinnema, C. (2014). Downgraded curriculum? An analysis of knowledge in new curricula in Scotland and New Zealand. Curriculum J. 25, 50-75. doi: 10.1080/09585176.2013.872047

Rata, E. (2012). The politics of knowledge in education. Br. Educ. Res. J. 38, 103-124.

Rennie, L., Venville, G., and Wallace, J. (2012). Knowledge that Counts in a Global Community: Exploring the Contribution of Integrated Curriculum. New York, NY: Routledge.

Riley, S. (2013). Pivot Point: At the Crossroads of STEM, STREAM and Arts Integration. Edutopia. Available online at: https://www.edutopia.org/ blog/pivot-point-stem-steam-arts-integration-susan-riley (accessed June 30, 2020).

Rittel, H. J., and Webber, M. M. (1973). Dilemmas in a general theory of planning. Policy Sci. 4, 155-169. doi: 10.1007/bf01405730

Romance, N. R., and Vitale, M. R. (2012a). Expanding the role of K to 12 science instruction in educational reform: implications of an interdisciplinary model for integrating science and reading. Sch. Sci. Math. 112, 506-515. doi: 10.1111/ ssm. 12000

Romance, N. R., and Vitale, M. R. (2012b). Science IDEAS: a research-based K-5 interdisciplinary instructional model linking science and literacy. Sci. Educ. 21, $1-11$.

Rotherham, A. J., and Willingham, D. (2009). 21st century skills: the challenges ahead. Educ. Leadersh. 67, 16-21.

Satchwell, R. E., and Loepp, F. L. (2002). Designing and implementing an integrated mathematics, science, and technology curriculum for the middle school. J. Ind. Teach. Educ. 39:4.

Sellar, S., and Lingard, B. (2014). The OECD and the expansion of PISA: new global modes of governance in education. Br. Educ. Res. J. 40, 917-931. doi: 10.1002/berj. 3120

Smithrin, K., and Upitis, R. (2005). Learning through the arts: lessons of engagement. Can. J. Educ. 28, 109-127.

Snapp, J. (2006). Implementing Curriculum Integration in Standards-Based Middle Schools: The Principal's Role. Westerville, OH: National Middle School Association.

Sylwester, R. (1995). A Celebration of Neurons: An Educator's Guide. Alexandria, VA: ASCD.

Taba, H. (1962). Curriculum Development: Theory and Practice. New York, NY: Harcourt.

Thomas, J. W. (2000). A Review of Research on Project-Based Learning. Available online at: http://www.bobpearlman.org/BestPractices/PBL_Research. pdf (accessed June 30, 2020).

Trent, A., and Riley, J. (2009). Re-placing the arts in elementary school curricula: an interdisciplinary, collaborative action research project. Perspect. Urban Educ. 6, 14-28.

Tyler, R. W. (1989). "Reflecting on the eight-year study," in Curriculum History: Conference Presentations from the Society for the Study of Curriculum
History, ed. C. Kridel (Lanham, MD: University of Press America), 93-203.

U.S. Department of Labor (1991). The Secretary's Commission on Achieving Necessary Skills What Work Requires of School. A SCANS Report for America 2000. Washington, DC: U.S. Department of Labor.

Upitis, R. (2011). Arts Education for the Development of the Whole Child. Toronto: ETFO.

Vars, G., and Beane, J. (2001). Integrative Curriculum in a Standards-Based World. Eric Digest. Available online at: https://files.eric.ed.gov/fulltext/ED441618.pdf (accessed June 30, 2020).

Vars, G. F. (1991). Integrated curriculum in historical perspective. Educ. Leadersh. 49, 14-15.

Vega, V. (2012a). Research-Supported PBL Practices that Work. Schools that work: Edutopia. Available online at: https://www.edutopia.org/stw-project-basedlearning-best-practices-new-tech-research (accessed June 30, 2020).

Vega, V. (2012b). Research-Based Practices for Engaging Students in STEM Learning. Schools that work: Edutopia. Available online at: https://www. edutopia.org/stw-college-career-stem-research (accessed June 30, 2020).

Vega, V. (2013). Integrated Studies Research Review: Evidence-Based Practices and Programs. Edutopia. Available online at: http://www.edutopia.org/integratedstudies-research-evidence-based-practices-programs

Voogt, J., and Roblin, N. P. (2012). A comparative analysis of international frameworks for 21st century competencies: Implications for national curriculum policies. J. Curriculum Stud. 44, 299-321. doi: 10.1080/00220272. 2012.668938

Watras, J. (2006). The eight-year study: from evaluative research to a demonstration project, 1930-1940. Educ. Policy Anal. Arch. 14, 1-20.

Weinberg, A. E., and Sample McMeeking, L. B. (2017). Toward meaningful interdisciplinary education: high school teachers' views of mathematics and science integration. Sch. Sci. Math. 117, 204-213. doi: 10.1111/ssm.12224

World Economic Forum (2016). New Vision for Education: Fostering Social and Emotional Learning Through Technology. Available online at: http://www3. weforum.org/docs/WEF_New_Vision_for_Education.pdf (accessed June 30, 2020).

Wraga, W. (1992). The core curriculum in middle school: retrospect and prospect. Middle Sch. J. 23, 16-23. doi: 10.1080/00940771.1992.11496044

Wraga, W. (1997). Patterns of interdisciplinary curriculum organization and professional knowledge of the curriculum field. J. Curriculum. Supervis. 12, 98-117.

Wrightstone, J. W. (1935). An evaluation of the integrated curriculum in the upper grades. Element. Sch. J. 35, 583-587. doi: 10.1086/457229

Young, M. (2010). The future of education in a knowledge society: the radical case for a subject-based curriculum. J. Pac. Circle Consort. Educ. 22, 21-32.

Young, M., and Muller, J. (2010). Three educational scenarios for the future: lessons from the sociology of knowledge. Eur. J. Educ. 45, 11-27. doi: 10.1111/j.14653435.2009.01413.x

Conflict of Interest: The authors declare that the research was conducted in the absence of any commercial or financial relationships that could be construed as a potential conflict of interest.

Copyright $\odot 2020$ Drake and Reid. This is an open-access article distributed under the terms of the Creative Commons Attribution License (CC BY). The use, distribution or reproduction in other forums is permitted, provided the original author(s) and the copyright owner(s) are credited and that the original publication in this journal is cited, in accordance with accepted academic practice. No use, distribution or reproduction is permitted which does not comply with these terms. 